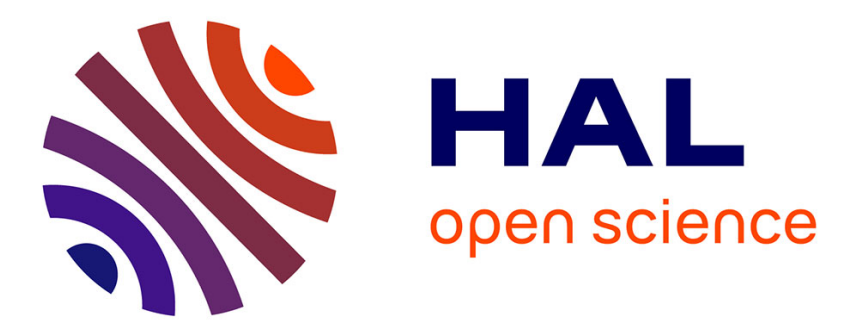

\title{
Putting Paris and Berlin on Show: Nightlife in the Struggles to Define Cities' International Position
}

Myrtille Picaud

\section{To cite this version:}

Myrtille Picaud. Putting Paris and Berlin on Show: Nightlife in the Struggles to Define Cities' International Position. Geoff Stahl; Giacomo Bottà. Nocturnes: Popular Music and the Night, Palgrave Macmillan, pp.35-48, 2019, Pop Music, Culture and Identity, 978-3-319-99786-5. 10.1007/978-3-31999786-5_3. halshs-02089282

\section{HAL Id: halshs-02089282 \\ https://shs.hal.science/halshs-02089282}

Submitted on 3 Apr 2019

HAL is a multi-disciplinary open access archive for the deposit and dissemination of scientific research documents, whether they are published or not. The documents may come from teaching and research institutions in France or abroad, or from public or private research centers.
L'archive ouverte pluridisciplinaire HAL, est destinée au dépôt et à la diffusion de documents scientifiques de niveau recherche, publiés ou non, émanant des établissements d'enseignement et de recherche français ou étrangers, des laboratoires publics ou privés. 


\title{
Putting Paris and Berlin on Show: Nightlife in the Struggles to Define Cities'
}

\section{International Position}

\author{
Myrtille Picaud
}

Postdoctoral fellow, Centre d'études européennes et de politique comparée, Sciences Po Paris

In Nocturnes. Popular Music and the Night, edited by Geoff Stahl and Giacomo Botta, Palgrave Macmillan, 2019.

\section{https://www.palgrave.com/gp/book/9783319997858}

\begin{abstract}
:
This chapter examines how local cultural policies, which draw on the 'alternative' music scene, participate to capital-cities' international positioning, within the context of strong competition between metropolises to attract investors and firms. Paris and Berlin serve as case studies. Territorial branding strategies rest on music venues in order to renew the cities' image, while these venues also serve as a focal point for spatial planning policies. In Berlin, urban renewal creates resistance among independent cultural intermediaries who feel threatened by the arrival of bigger players in the cultural industries, towards which public policies are geared. In Paris, public support for festive events organized in neighbouring cities participates in gentrification processes, as well as to the symbolic overtaking of the margins by the centre.
\end{abstract}

Culture is central to the cities' positioning and urban marketing (Breux, Collin, and Négrier 2007; Dubois 2012), as shown by the growth in festivals, aimed at galvanising local economic development (Gotham 2005; Négrier and Jourda 2007). In many cities, local urban policies resort to culture, namely in the sake of socio-cultural animation (Arnaud 2008; Faure and Garcia 2008; Laborier 1998). Indeed, urban and cultural policies are significantly intertwined (Sacco, Ferilli, and Blessi 2014) and increasingly include public-private partnerships. Some 
scholars go as far as mentioning the "festivalization" of politics and urban development (Festivalisierung der Stadtpolitik) (Häussermann, Siebel, and Birklhuber 1993). For other researchers, new forms of governmentality are shaping an urban order based on standards of creativity, flexibility and individuality (Marquardt et al. 2013).

These issues are salient when looking capital cities such as Paris and Berlin, which both appear in international rankings that draw on a variety of indicators, amongst which cities' "cultural experience". Paris' position in AT Kearney's "Global cities outlook" in 2017 or PricewaterhouseCoopers "Cities of opportunity" in 2016 have prompted enthusiastic responses from the City Offices, underlining how important these rankings have become in the international competition to become the most central "global cities" (Sassen 2001; Brenner and Keil 2014). Berlin, a much poorer and less economically developed capital, still lags behind but is gradually improving its place. Its cultural scene, which represents an important part of local employment compared to other German cities (Bocquet and Laborier 2016), is instrumental in its international repositioning. Indeed, the 'rebirth' of the local music scene after the fall of the Wall in 1989 (although the West of Berlin was already known through artists such as Nina Hagen, Einstürzende Neubauten or David Bowie), with the opening of many underground venues or squats in the East, and the spread of electronic music, have contributed to the German capital's renown (Stahl 2014). Today, Berlin still has many DIY venues and its music scene remains generally less professionalised and publicly subsidised (except for classical music) than in a city such as Paris (Picaud 2017).

Drawing on Paris and Berlin as case studies, this chapter examines how nightlife, and more specifically the music scene, takes part in struggles to define a city and its international image. This chapter relies on interviews with around sixty bookers (thirty in each city) and persons in charge of cultural policies in both capitals. Although interviewed bookers worked in diverse venues (auditoriums, theatres, clubs, etc.), I will focus here on those presenting 
themselves as "alternative" and DIY locations. Fieldwork was conducted between 2012 and 2016 in both capitals. I also contrasted the bookers' and public authorities' discourse with ethnography during concerts in many different venues and data on policies and urban transformations in both cities.

I will first show that in Berlin, music venues are increasingly used as touristic attractions and contribute to the city's urban marketing (Lucarelli and Olof Berg 2011) as a 'creative city' (about the use of Richard Florida's ideas in cities' policies, see Lanz 2013) and to economic development (similarly to other places, such as the UK, see Chatterton and Hollands 2003). The private agencies that manage the City of Berlin's branding exploit the music scene's "subcultural capital” (Thornton 1995) in order to develop its image as an innovative city for start-up creators. We will then see that this, however, does not happen without awaking resistances within the music scene. Finally, I will show that in Paris, the issues are slightly different. In a city where nightlife was once judged 'dead', the renewal of parties is also perceived as a touristic asset, while also participating to the economic and urban project of symbolically integrating the urban margins into the centre.

\section{Dramatizing Berlin's subcultural capital to develop the city's economy}

Former Mayor Klaus Wowereit is known to have said that "Berlin is poor but sexy", in 2003. This statement however is not only a catchy phrase; it underpins a more global strategy in the city's territorial branding that emphasises its links with subculture. Indeed, its international marketing draws on specifically on "youth and club cultures" (Colomb 2012, 230), on which the City's public authorities (Senate Department for Economics, Technology and Women) have commissioned different surveys, such as the one undertaken by the Club Commission (a

\footnotetext{
${ }^{1}$ «Berlin ist arm, aber sexy. »- Interview mit Focus Money, Novembre 2003, https://de.wikiquote.org/wiki/Klaus_Wowereit, consulté le 21.07.2016.
} 
professional organization representing rather alternative clubs in the city) in cooperation with the Centre for Political, Cultural and Research Berlin. This report identifies the club scene as a future "international figurehead for Berlin" (Kretschmar and Grigutsch 2007, 15) and also refers to Richard Florida's (Florida 2005) contested (see Krätke 2010) theories in order to push the agenda on the city's economic development through culture (Kretschmar and Grigutsch 2007, 5). However, drawing on countercultural scenes in order to further economic development or political reform is nothing new in Berlin. Indeed, even before the fall of the Wall, the countercultural scenes in West-Berlin inspired reforms involving the withdrawal of the state from the city's underprivileged neighbourhoods, through the promotion of selforganized communities, and individual initiatives and flexibility (Lanz 2014, 62). This approach satisfied the conservative forces of the CDU party, but could also be combined with the values of some members of the countercultural scenes, mainly German nationals belonging to the middle classes, well endowed with cultural capital. They were better prepared than others to adapt to reforms of the welfare state. According to Stephan Lanz, West Berlin's urban and cultural policy thus became a key instrument of social governance. This policy was perpetuated after 1989, in the context of a neoliberal era promoting the entrepreneurial self, whose values are particularly attuned with the those in the "creative industries". Berlin's local policy thus gradually shifted from a "capital of all Germans" towards a "creative city", which "manifested itself (among other ways) in the city's attitude towards informal subcultural appropriations of space (clubs, bars, street art, etc.)" and was also rapidly undertaken by private investors seeking to recycle 'wastelands' (Lanz 2013, 1314). Some urban districts [Bezirk], such as Kreuzberg-Friedrichshain, have facilitated the opening of clubs and music venues since the 2000s as a way to redevelop local economic activity. 
The city's recent turn towards the more lucrative digital sector and start-ups has led to a transformation in its territorial branding (Davis 2013) (to which Berlin devoted five million euros in 2004, against four for Hamburg (Jacobsen 2009)). The idea of poverty (arm aber sexy) has been abandoned but the catchphrase retains the idea of authenticity: "be Berlin". Alternative culture plays an important role in this campaign. Partner Berlin, a private firm in charge of the city's tourism policy and the Club Commission organized a conference entitled "20 years of club culture in Berlin". The be Berlin website reports about this event and establishes a clear link between touristic and economic development on one hand and the music scene on the second. Partner Berlin's Managing Director states:

No other city in the world currently enjoys a club culture as lively as Berlin. [...] The music and club scene has become a significant factor of economic development. Around 300 clubs and concert venues employ about 8,000 people and generate approximately 170 million euros in 2005. [...] In addition, clubs in the city attract many tourists from around the world and stimulate the hotel and restaurant industries ${ }^{2}$.

The promotion of alternative club cultures seems to partake in strategies establishing Berlin's status as a cultural capital. This also distinguishes it from its European counterparts by stressing its "subcultural capital", since it can until now hardly compete on the economic level. For example, Christian Tänzler, Head of Communications at the VisitBerlin Tourist Office, stated:

it is obvious that the automobile industry is rather present in the South; banks are in Frankfurt, trade in Hamburg [...]. In financial terms, we are not Shanghai, Hong Kong, London or New York. But perhaps it is necessary to distinguish between a world metropolis and a world city. For Berlin undoubtedly has a global dimension in certain

\footnotetext{
${ }^{2}$ Translated by author, «Sei Club, sei Party, sei Berlin », http://www.sei.berlin.de/presse/sei-club-sei-party-seiberlin-berlin-ist-musikstandort-nr-1, browsed on 02.02.2017.
} 
areas, in the realm of freedom, culture or subcultures. Where is the creative scene, startups, music? [...] On these issues, Berlin is undoubtedly central on the international scene. (quoted in Vannier 2015, translation by author)

Although alternative venues are instrumental in the way public authorities portray and sell Berlin, it is not necessarily favoured by the way policies are implemented. Prioritizing global competitiveness through a service-oriented post-Fordist metropolis (Colomb 2012) and the use of culture to foster urban renewal and processes of gentrification has indeed had positive consequences for other actors, such as corporate venues or cultural spaces. Case in point is the future public square named Mercedes Platz (a telling name), after Mercedes Benz. It is a commercial and cultural project in the surroundings of the legendary Berghain nightclub. Starting from the end of 2018, it is planned to host a movie theatre with 2500 seats, a bowling alley, fifteen restaurants, a music venue (4000 seats), 10,000 square meters of offices, two hotels with nearly four-hundred rooms and meeting rooms for the multinational firm Daimler AG. Driven by a partnership between Mercedes and Anschutz Entertainment Group, the project is expected to cost 200 million euros. This new shopping centre, located in the East in Friedrichshain, is an extension of the Mercedes-Benz Arena (17,000 seats) and will occupy 20,000 square meters. Quite ironically, the construction of the Mercedes Benz Arena had already driven the Berghain owners away from their first location, called Ostgut, which closed in 2003. The current Berghain will not be destroyed by the construction of the Mercedes Platz - nevertheless, one may wonder about what will become of its "alternative" atmosphere in the midst of such a commercial environment.

This recapitalization of the city reshapes the urban fabric and directly threatens some alternative venues in Berlin. Moreover, putting Berlin on show by making an instrumental use of its alternative scenes has amplified oppositions within the music scene. 


\section{Resisting territorial branding within the alternative music scenes}

Many cultural intermediaries that I interviewed within the music scene resist the way Berlin is being portrayed by public authorities and stress its negative outcomes. Among these, gentrification, rising rents ultimately forcing venues to close and pushing the alternative music scene away from the centre. However, their position is often ambivalent, because they sometimes participate to these marketing campaigns and most of them benefit from tourism, which brings guests to their clubs.

The communication director of a large professional organisation for clubs in Berlin explains that his approach differs from the city's marketing of the city because he promotes the artistic side of the scene. He refuses to emphasize only a festive aspect, that distorts the scene's authenticity and conveys its commodification:

We are trying to [intervene] in issues about club scene, music scene, we also represent the scene abroad, like we do projects in Brazil, in Warsaw, in Switzerland, we also went to Cairo this year, we try to take it out of the hand of the City marketing, and say we can do it better, because we do it more authentic, and we involve people from the scene into our projects, when we go abroad, we try to do very authentic. Because we don't want typical party tourism, we want music-driven tourism. I don't think the people in the city marketing can do the difference between that. (Gary ${ }^{3}$, public relations manager in Berlin clubs' professional organisation, interview in Berlin on $3^{\text {rd }}$ Dec. 2013)

Although the political exploitation of the music scene's subcultural capital in order to develop tourism and the local economy is regularly criticized, many alternative music bookers travel abroad and share their know-how and experiences at national or international music fairs. At least four out of the thirty interviewed bookers have even created agencies and sell their

\footnotetext{
${ }^{3}$ All names have been changed and replaced by similar ones, in order to respect bookers' demands for anonymity.
} 
"alternative" expertise to local public or cultural administrations who aim at developing striving nightlife quarters. Although they emphasise the difference between the City's and their own approach, they nonetheless participate in the ongoing discourse about the post-1989 Berlin revival and contribute to the capital's "alternative" image. This also reinforces their position within the international music scene, particularly within the field of electronic music. Indeed, in Paris, several bookers that I met mention their links with renowned Berlin clubs to legitimize their own clubs and musical choices, to show that they too promote artists 'off the beaten track'. Ties with bookers from Berlin are presented as guarantees of this:

(T)hey are people [cites bookers from the Berghain and the Tresor] who test us, they want... Well, it's not enough to just make a big check. It's really having a spirit, making good line-ups, good parties, having the right audiences and good sound: the sound, the sound, the sound in the venue." (Tania, booker in a large Parisian electronic music venue, interview conducted in Paris on $16^{\text {th }}$ April 2014)

However, many bookers in Berlin feel that their activity is endangered by the gentrification in the centre of the city, caused by economic development and new urban projects. Indeed, gentrification ultimately drives them out of the neighbourhoods where their venues are located, as the rents become too expensive, but supposedly also because 'gentrifiers' no longer tolerate the noise caused by the clubs' presence and sue them. The Knaack club, opened from 1952 to 2010, is an example that is often referred to during interviews. Located in Prenzlauer Berg (East), the venue hosted groups such as Rammstein and Die Toten Hosen. Following the construction of a building with a joint wall with the venue, new tenants filed a complaint against the club because of the noise. According to a one booker, the firm in charge of the construction did not follow the guidelines and insufficiently isolated the walls in order to soundproof the club. The club was destroyed and another building replaced it. Since this happened, Berlin's Senate announced a new legal framework in order to avoid closing club 
because of complaints due to noise, when the venue is proven to have been there before new tenants or owners: "Our goal is for Berlin to remain thrilling and wild ${ }^{4}$," Andreas Geisel, Head of Urban Development at the City Hall, stated. The MusicBoard, a public agency supported by the Senate that promotes pop music, has thus started listing venues and their location to prove their existence, a census whose importance is central within these struggles. In addition, rent control was implemented in 2015.

Bookers' concerns about gentrification also reflect fears about the 'gentrifiers', often assimilated to 'tourists' who dilute local codes and practices in the alternative scene. Much has indeed been written about the "Easyjetsetters" (the term was popularised by music journalist Rapp 2009) who are said to fly to Berlin just to party, with no interest for the local scene. One booker in an alternative venue states:

“(I)t's hard, especially for us, because traditionally, our guests are from Berlin, or from Kreuzberg, and as Berlin and Kreuzberg change so much, like you know, all the gentrification, and we feel it from the people who come here, and lots of people can't afford to live here anymore, so yeah of course we don't like the gentrification too much. But as well, lots of tourists come here from all over the place, or all over the world, but they come to Kreuzberg, because they are looking for that alternative feeling, but it's fading away more and more." (Nini, booker in a renowned mid-sized venue in Kreuzberg, opened in the 1970s, rock, punk, electronic music, woman, 45 years old, interview in Berlin, $31^{\text {st }}$ Oct. 2013)

So-called 'tourists' - although it is often difficult to say which groups are subsumed under this designation - are perceived as causes of a lesser subversion and an increasing commercialization within the music scene. Recurring judgements about 'gentrifiers',

\footnotetext{
${ }^{4}$ Vincent Glad, « À Berlin, ce sont les voisins qui devront s'adapter, pas les clubs », Konbini, 2015, http://www.konbini.com/fr/tendances-2/clubs-berlin-voisins/, browsed on 05.04.16.
} 
commercialisation and tourism point to the difficulty alternative bookers have dealing with the massification of audiences and their social diversification. Although these newcomers allow their clubs to survive economically, the failure of many of them to abide by the rules organising the alternative scene reveals a lack of subcultural capital (Thornton 1995). This situation is creating a growing unease and conflict amongst cultural intermediaries, since younger bookers or those who have recently arrived in Berlin from other German cities or countries do not resent this situation as do more ancient local figures. The legendary waitinglines in front of successful venues such as the Berghain and the rumours about who gets in or not, the many clubs proscribing pictures within their premises and those who keep their addresses secret can seem to be fads or postures. But they also give evidence of practices regulating access to alternative places and forms of resistance against the city's indiscriminate marketing of its subcultural capital.

These resistances are also evidenced in explicitly political actions, which challenge some of the Senate's choices. MediaSpree, a project of urban development that promotes creative industries was opposed (most notably by MediaSpree Versenken) due to its privatisation of the city's riverbanks, the importance of multinational corporations within it and the displacement of pre-existing cultural venues, such as Yaam. Special floats were paraded during the Karneval der Kulturen festival by cultural intermediaries, including Yaam, symbolising resistance against this project. Demonstrations also took place against Berlin hosting the Olympic Games in $2000^{5}$. These actions sometimes prevented the realization of these projects and hindered some forms of economic development, meanwhile safeguarding many "alternative" spaces in the city. In Paris, the urban night plays a very different role,

\footnotetext{
5 “'(T)he Olympic Games, I think it was 1992 [2000], I'm not really sure. There was this, in the aftermath of the reunification, I guess the political classes decided that they wanted money and to like really build Berlin. And so the Olympic Games were seen as a possibility to get enough money on a heap to do that. And there was a major popular movement, to basically throw them out. [...] They basically didn't dare to put it in Berlin, the Olympic international committee decided on Sydney." (Konstantin, booker in a small experimental music venue in Prenzlauer Berg, interview in Berlin on the $18^{\text {th }}$ Nov. 2013)
} 
although it is also (perhaps more willingly?) used by public authorities to reinvent the city's image. I will shortly comment on this.

\section{Thoughts from Paris: rich, but sexy nonetheless?}

In Paris, a global city that concentrates many economic resources and centralises an important part of cultural employment and production, the music scene has recently been included in strategies destined to revive the city's image. Indeed, clubs and parties seemed a perfect antidote for a capital that some stated was "dead", and that other feared was morphing into a museum of past glories. Public authorities' renewed interest in the music scene developed after diverse club owners and music intermediaries released an open letter entitled "When nightlife dies in silence" time" political agenda, the City Hall appointing a 'Night' deputy to the Mayor as well as a "Council of the Night". This is gradually leading to the development of a horizontal public policy bridging tourism, economic development, urban, social and cultural policies. A more vibrant club and party scene has been deemed an essential asset in the expansion of tourism, in order to change Paris' museum-like image. It also functions as a driving power for urban renewal and to change local representations about different neighbourhoods and the poorer outskirts of the city.

These issues are particularly salient when looking at the renewal or electronic music events in industrial locations situated in the outskirts of Paris, mainly in poorer and left-wing cities. These parties are often organised by non-for-profit collectives and private agencies

6 "Quand la Nuit meurt en silence", open letter from intermediaries in the music and nightlife scene, le 19.10.2009, to the French Interior Ministry, Ministry of Culture, Paris City Hall and Police authorities. Read online:

http://www.lespierrotsdelanuit.org/download/download.php?file=/wmedias/documents/lettre_ouverte technopol. pdf, browsed on 03.20.2016 
(Soukmachines, Surprize, Sonotown, Microclimat, 75021, Berlinons Paris, Die Nacht, Cracki

Records, to name a few) or in venues that have diverse statuses (legal or not) and lifespans (6B in Saint-Denis, L'Amour in Bagnolet, La Ferme du Bonheur in Nanterre, L'atelier Wonder in Saint-Ouen, le Tunnel in Issy-les-Moulineaux, the Freegan Poney and La Station in the North of Paris, etc.). Many of these places are old industrial buildings that are squatted, have temporary leases or were attributed by local authorities. For example, since June 2016 the Parisian Region (Ile-de-France) has launched a call to promote "urban innovation and impulse economic development dynamics, to generate added value within local territories ${ }^{7}$, , which aims at temporarily occupying and animating empty buildings that are due to be destroyed or renewed. These projects avoid squatting and revalue the local real estate market. They contribute to changing the representations about neighbourhoods predominantly inhabited by poorer and working-class populations.

This is very visible when looking at media discourses about these parties. The "renewal" of parties on the outskirts of Paris is a central topic amongst music bookers, but also in the press (Libération, les Inrocks, Street Press, Konbini) or in advertorial magazines. The images conveyed by the press are largely informed by an opposition between a "civilized" but boring intramuros Paris, and untamed working class "suburbs" (about this notion's social and political construction, see Tissot 2007) that are perceived as more free and authentic. According to some organisers, these events have changed the way these "suburbs" are perceived, although by stating this they continue to convey stereotypical images of these. Here, one of them cites Saint-Denis, a city on the outskirts of Paris that is often portrayed as poor and dangerous:

\footnotetext{
${ }^{7}$ Author's translation, « Soutien aux initiatives d'urbanisme transitoire », https://www.iledefrance.fr/aidesregionales-appels-projets/soutien-aux-initiatives-urbanisme-transitoire, browsed on 03.02.2017.
} 
Even three years ago, when we spoke of Saint-Denis to a young person, she immediately thought civil war, says Eric Labbé [PR manager for clubs in upper-class Parisian neighbourhoods], the co-author of the open letter 'When nightlife dies in silence' in 2009. Today, a place like the 6B [a legal but non-profit building-club in Saint-Denis] has transformed that city's imaginary. It gave her a sexier image, and now large gatherings are taking place in the suburbs. ${ }^{8}$

Press articles about parties and events in the "suburbs" often compare these to Berlin, seemingly a reference when it comes to appropriating cultural spaces in what are perceived as industrial wastelands:

Although two old train stations on the fringes of Paris are actually being renovated and will become multidisciplinary venues $[\ldots]$ you must still go even further from the centre to spend unforgettable nights that recall the Berlin dreamed of by many clubbers..." Some collectives even have names directly referring to Berlin, such as Berlinons Paris (Let's Berlin-ize Paris) or Die Nacht, whose "house and techno events are inspired by what is happening in Berlin or London and invest original places ${ }^{10}$ '. References to Berlin are thus used to authenticate these events as 'alternative' and by doing so also contribute to portraying these 'suburbs' as gritty and appealing to organisers and audiences that mostly come from inner Paris. Cultural events thus participate to the symbolic integration of the margins by the centre, a project that is coherent with the current development of the Grand Paris, a political and administrative project encompassing the city and its nearest suburbs in a unique administrative structure.

\footnotetext{
${ }^{8}$ Author's translation, Vianney Delourme, « Le Grand Paris est une fête - Libération », Libération, 10.15.2015, http://www.liberation.fr/debats/2015/12/10/le-grand-paris-est-une-fete 1419742, browsed on 12.15.2015.

${ }^{9}$ Translation by author, "Les soirées Blank, les Ambassadeurs... la banlieue bouge !", Villa Schweppes, 02.19.2014, http://www.villaschweppes.com/article/les-soirees-blank-les-ambassadeurs-la-banlieuebouge a4023/1, browsed on 07.05.2016.

${ }^{10}$ Translation by author, Lorraine Grangette, "Les collectifs techno et fêtes éphémères | Clubbing | Paris", 04.07.2016, http://www.timeout.fr/paris/concert-soiree/collectifs-techno, browsed on 04.11.2016.
} 


\section{Conclusion}

Although alternative venues at first developed outside of city planner's scope of interest, public authorities soon realised that this "subcultural capital" was instrumental in redefining the way their capital was perceived abroad. In Berlin as in Paris, nightlife is instrumental to touristic and urban policies, which are linked to the city's economic development. In Berlin, territorial marketing has been used to develop a "creative" city. Although the urban landscape is rapidly changing, Berlin's economy has until now failed to follow along with most of its Western European counterparts. These policies have fostered oppositions within the music scene, fearing for its subversive dimensions. It is possible, however, that the gradual renewal amongst cultural intermediaries will in time stifle these resistances. In Paris, the alternative scene is transforming the way working class suburbs are perceived by the centre. While this might at first resemble a reversal of stigma, it can increasingly be analysed as a process accompanying the French capital's economic and urban extension beyond its traditional borders. While public authorities attempt to put their capital on show, urban spaces are changed to a musical score, thus revealing the political potential that still lies within 'the Night'.

\section{Bibliography}

Arnaud, Lionel. 2008. Réinventer La Ville. Artistes, Minorités Ethniques et Militants Au Service Des Politiques de Développement Urbain : Une Comparaison FrancoBritannique. Rennes: Presses Universitaires de Rennes.

Bocquet, Denis, and Pascale Laborier. 2016. Sociologie de Berlin. Paris: La Découverte. Brenner, Neil, and Roger Keil. 2014. 'From Global Cities to Globalized Urbanization'. Glocalism: Journal of Culture, Politics and Innovation 3. 
Breux, Sandra, Jean-Pierre Collin, and Emmanuel Négrier. 2007. 'Political Rescaling and Municipal Cultural Public Policies: A Comparison of France and Québec'. International Journal of Urban and Regional Research 31 (1): 128-45.

Chatterton, Paul, and Robert Hollands. 2003. Urban Nightscapes: Youth Cultures, Pleasure Spaces and Corporate Power. London: Routledge.

Colomb, Claire. 2012. Staging the New Berlin: Place Marketing and the Politics of Urban Reinvention Post-1989. London: Routledge.

Davis, Aeron. 2013. Promotional Cultures: The Rise and Spread of Advertising, Public Relations, Marketing and Branding.

Dubois, Vincent, ed. 2012. Le Politique, l'artiste et Le Gestionnaire. (Re)Configurations Locales et (Dé)Politisation de La Culture. Vulaines sur Seine: Editions du Croquant. Faure, Sylvia, and Marie-Carmen Garcia. 2008. 'Hip-Hop et politique de la ville'. Agora débats/jeunesses 49 (3): 78-89.

Florida, Richard. 2005. Cities and the Creative Class. London; New York: Routledge.

Gotham, K. 2005. 'Theorizing Urban Spectacles: Festivals, Tourism and the Transformation of Urban Space'. City, no. 9: 225-46.

Häussermann, Hartmut, Walter Siebel, and Daniela Birklhuber. 1993. Festivalisierung Der Stadtpolitik. Stadtentwicklung Durch Große Projekte. Opladen: Leviathan Sonderheft 13, Westdeutscher Verlag.

Jacobsen, Björn P. 2009. 'Investor-Based Place Brand Equity: A Theoretical Framework'. Journal of Place Management and Development 2 (1): 70-84.

Krätke, Stefan. 2010. “"Creative Cities” and the Rise of the Dealer Class: A Critique of Richard Florida's Approach to Urban Theory'. International Journal of Urban and Regional Research 34 (4): 835-53. 
Kretschmar, Olaf, and Rainer Grigutsch. 2007. 'Studie Über Das Wirtschaftliche Potenzial Der Club Und Veranstalterbranche in Berlin'. Berlin: Senatsverwaltung für Wirtschaft, Technologie und Frauen, Landesinitiative Projekt Zukunft.

Laborier, Pascale. 1998. 'La Soziokultur En RFA. D’un Enjeu Politique à l'institutionnalisation d'une Catégorie d'intervention Publique'. In Politiques Locales et Enjeux Culturels. Les Clochers d'une Querelle XIXe-XXe Siècles, edited by Vincent Dubois and Philippe Poirrier, 299-321. Paris: La Documentation Française.

Lanz, Stephan. 2013. 'Be Berlin! Governing the City through Freedom'. International Journal of Urban and Regional Research 37 (4): 1305-24.

—. 2014. 'Inclusion and Segregation in Berlin, the "Social City"'. In Transnationalism and the German City, by Jeffry M. Diefendorf and Janet Ward, 55-71. New York; Basingstoke, UK: Palgrave Macmillan.

Lucarelli, Andrea, and Per Olof Berg. 2011. 'City Branding: A State-of-the-art Review of the Research Domain'. Edited by Ares Kalandides. Journal of Place Management and Development 4 (1): 9-27.

Marquardt, Nadine, Henning Fuller, Georg Glasze, and Robert Putz. 2013. 'Shaping the Urban Renaissance: New-Build Luxury Developments in Berlin'. Urban Studies 50 (8): $1540-56$.

Négrier, Emmanuel, and Marie-Thérese Jourda. 2007. Les nouveaux territoires des festivals. Paris: Michel de Maule.

Picaud, Myrtille. 2017. 'Mettre La Ville En Musique (Paris-Berlin). Quand Territoires Musicaux, Urbains et Professionnels Évoluent de Concert'. Thèse de Sociologie, Paris: Ecole des Hautes Etudes en Sciences Sociales.

Rapp, Tobias. 2009. Lost and Sound: Berlin, Techno Und Der Easyjetset. Berlin: Suhrkamp / Insel. 
Sacco, Pierluigi, Guido Ferilli, and Giorgio Tavano Blessi. 2014. 'Understanding Culture-Led Local Development: A Critique of Alternative Theoretical Explanations'. Urban Studies 51 (13): 2806-21.

Sassen, Saskia. 2001. The Global City: New York, London, Tokyo. Princeton, NJ: Princeton University Press.

Stahl, Geoff, ed. 2014. Poor But Sexy: Reflections on Berlin Scenes. Bern: Peter Lang.

Thornton, Sarah. 1995. Club Cultures Music, Media and Subcultural Capital. Hoboken: Wiley.

Tissot, Sylvie. 2007. L'État et Les Quartiers. Genèse d'une Catégorie de l'action Publique. Paris: Seuil.

Vannier, Sébastien. 2015. 'Berlin, l'aimant Tant Aimé'. In L'Allemagne Change! Risques et Défis d'une Mutation, edited by Hans Stark and Nele Katharina Wissman, 155-66. Villeneuve d'Ascq: Presses universitaires du Septentrion. 